\title{
PROSPECÇÃO DE FONTES NATURAIS DE ANTOCIANINAS PARA ESTUDOS DE PROPRIEDADES E APLICAÇÕES DESSES COMPOSTOS
}

\author{
Gabriel Guerra, Larissa S. da Fonseca, Isabella Capistrano, Ivo B. de Freitas, Lilian Patricia Lima, Acacia A. \\ Salomão e Adriana V. Rossi
}

\section{Resumo}

Antocianinas são as principais responsáveis por inúmeras tonalidades de cores encontradas em flores, frutas e folhas. São substâncias naturais do grupo dos flavonóides e servem para pigmentação por apresentarem coloração que varia do vermelho até o violeta. O objetivo principal desse projeto foi produzir tintas naturais a base de antocianinas, avaliando sua aplicabilidade e estabilidade em tecidos de algodão e de papel, utilizando extrato de amora (em solução aquosa de ácido cítrico 3\%) e testar outras potenciais fontes de corantes e pigmentos, como açafrão, beterraba e urucum para o tingimento dos substratos.

\section{Palavras-chave:}

Pigmentos naturais, antocianinas, tingimento de tecidos.

\section{Introdução}

Antocianinas são compostos bastante solúveis em água, tendo uma composição estrutural complexa e podendo apresentar várias cores tais como laranja, vermelho e azul, sendo presentes em flores, frutas, hortaliças, folhas e raízes. A sensibilidade ao $\mathrm{pH}$ é o principal fator limitante no processamento e utilização das antocianinas, pois afeta sua cor e sua estabilidade química (XAVIER; LOPES et al., 2007). A cor também pode ser afetada por exposição a luz e temperatura entre outros fatores. A variedade de cores torna interessante seu uso como corante para produção de tintas naturais. Corantes sintéticos dominam as aplicações no mercado alimentício e de tecidos, principalmente devido à alta estabilidade, maior capacidade de pigmentação, fixação, produção de cores mais intensas e consequentemente, menor custo, já que pequena quantidade confere cor intensa. Devido a proibição do uso de alguns corantes sintéticos pela sua toxicidade, há um crescente interesse no estudo de corantes provenientes de fontes naturais (FAVARO, 2008). Dessa forma, o objetivo desse projeto é o estudo do tingimento de tecidos de algodão e de papel, a base de extratos naturais. Como as antocianinas possuem baixa estabilidade às variações de condições de uso, outros corantes naturais provenientes de outras fontes vegetais também foram estudados.

\section{Resultados e Discussão}

Após um teste inicial feito em tecido de algodão cru, foram definidos que os extratos naturais utilizados no restante do projeto seriam os extratos de amora, açafrão, beterraba e urucum. Para serem comparáveis com o extrato de amora, onde há a presença de antocianinas, todos os extratos foram obtidos através da extração de sua fonte vegetal em solução aquosa de ácido cítrico $3 \%$ a $60^{\circ} \mathrm{C}$ por uma hora, seguida de filtração. A presença de antocianinas no extrato de amora foi confirmada por testes de caracterização visual das antocianinas em diferentes pHs, pelo teste de reversibilidade do equilíbrio ácido-base e pela sua caracterização espectrofotométrica.
Para os testes de tingimento, foram utilizados como substratos papel A4, pedaços de tela de algodão cru e pedaços de sacola ecobag. Em todos os substratos foi observado o tingimento, principalmente quando este era aquecido junto com o extrato vegetal, aumentando a velocidade de fixação dos extratos. Os extratos de beterraba e urucum foram os que tiveram a menor fixação, provavelmente porque sua extração não foi completa (baixa solubilidade do extrato em água).

Para avaliar a fixação dos pigmentos nos substratos, foram realizados testes de lavagem, de transferência de cor e de degradação expondo os substratos tingidos sob ação da luz e da temperatura. Em todas essas condições foram observadas a descoloração dos substratos ao longo do tempo, sendo as mais significativas nos testes sob ação da temperatura e sob lavagem com agitação mecânica. Isso indica que novos estudos são necessários para entender como se dá a interação química entre os pigmentos-substratos e como favorecê-las em detrimento de sua degradação.

\section{Conclusões}

As tintas naturais produzidas a partir dos extratos têm potencial para serem utilizadas no tingimento de tecidos de algodão, principalmente as obtidas a partir da amora e do açafrão conforme nos indicou o estudo realizado. Contudo, foi possível identificar que as tintas naturais produzidas sofrem mudanças de tonalidade ao decorrer do tempo em função da sua degradação natural, exposição a mudanças de temperatura ou luminosidade, ou de processos de lavagem. Dessa forma novos estudos são necessários para entender sua fixação nos tecidos e prevenir sua degradação ao longo do tempo.

\section{Agradecimentos}

Agradecemos ao Conselho Nacional de Desenvolvimento Científico e Tecnológico - CNPq pelas bolsas de estudo e pelo apoio à pesquisa.

FAVARO, M. M. A. Extração, estabilidade e quantificação de antocianinas de frutas típicas brasileiras para aplicação industrial como corantes. 2008. Dissertação (Mestrado em Química) -Instituto de Química, Universidade Estadual de Campinas, Campinas

LOPES, T. J.; XAVIER, M. F.; QUADRI, M. G. N.; QUADRI, M. B. Antocianinas: uma breve revisão das características estruturais e da estabilidade. Revista Brasileira de Agrociência, v. 13, n. 3, p. 29 